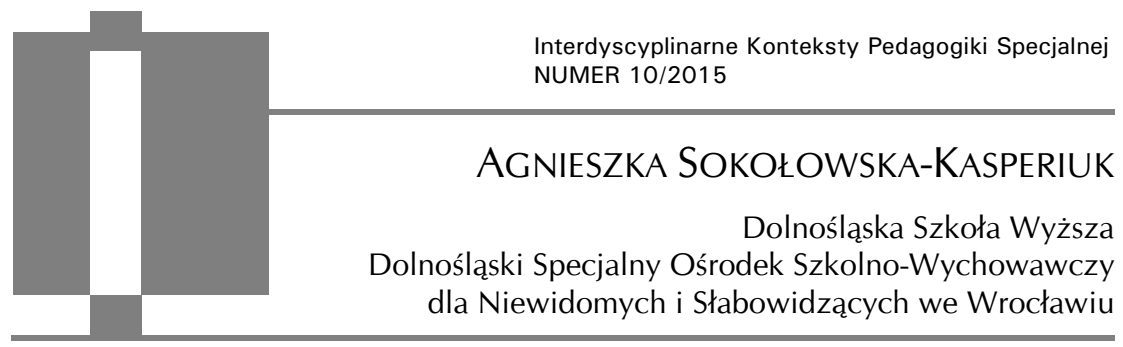

\title{
Blaski i cienie życia dorosłej osoby ociemniałej w kontekście przystosowania się do niepełnosprawności. Studium przypadku
}

ABstract: Agnieszka Sokołowska-Kasperiuk, Blaski i cienie życia dorostej osoby ociemniałej w kontekście przystosowania się do niepetnosprawności. Studium przypadku [Brightness and shadows on the way of life of the adult blind person in the context of being in the process of adaptation to disability. A case study]. Interdyscyplinarne Konteksty Pedagogiki Specjalnej, nr 10, Poznań 2015. Pp. 155-180. Adam Mickiewicz University Press. ISSN 2300-391X

The article contains the information about diagnostic and functional differences between people blind from the birth and who lost sight during their lives. There are also described some functional consequentions of visual disability. The basic aim of the article is showing the psychological, social and physical situation of a blind person. The author uses examples from life of a particular person in a context of the process of adaption to disability (a case study).

KEY WORDS: visual disability, a blind person, process of adaptation to disability 


\section{Wprowadzenie}

Wzrok dostarcza człowiekowi około $80 \%$ informacji o otoczeniu, stąd też jego utrata - zwłaszcza, kiedy następuje w sposób gwałtowny i nieoczekiwany - burzy postrzeganie rzeczywistości w stopniu niewyobrażalnym, zmienia zakres oraz rodzaj kontaktów z innymi ludźmi, ogranicza niezależność oraz dostęp do pracy, nauki czy kultury. Wszystkie te elementy wyzwalają konieczność przeformułowania całego życia, znalezienia nowych sposobów poruszania się, komunikowania, postrzegania swoich możliwości. Bohaterce niniejszej opowieści - pani Lenie, przyszło się zmierzyć z takim wyzwaniem. Jej doświadczenia stały się kanwą opowieści o niezależności, odwadze oraz samodzielności osoby ociemniałej, która przeszła niełatwą drogę, stoczyła niejedną bitwę ze światem i samą sobą. Emancypacja, jaką w sobie wyzwoliła, płynie dziś nie tylko z doświadczania codziennej akceptacji ze strony innych, lecz przede wszystkim siebie samej i swojej sytuacji. Podstawowym celem niniejszego opracowania nie jest jednak gloryfikacja bohaterki, lecz próba ukazania złożonej sytuacji osoby tracącej wzrok w dorosłości oraz wyzwań, z jakimi musi się mierzyć.

\section{Osoba niewidoma a ociemniała - najistotniejsze różnice}

Wśród osób niewidomych niewiele jest dotkniętych całkowitą utratą wzroku. Większość zachowuje poczucie światła lub szczątkowe widzenie umożliwiające np. rozpoznanie okna czy wnęki $\mathrm{w}$ korytarzu w postaci plamy światła. Informacje te mają duże znaczenie dla codziennej orientacji $\mathrm{w}$ przestrzeni. Klasyfikacja stosowana przez WHO podąża za tym istotnym ze względów funkcjonalnych kryterium, umożliwiając diagnozę utraty wzroku w przypadkach: 
a) zupełnego braku wzroku (visus 0,00$)$,

b) ostrości wzroku nie przekraczającej 0,05 normy w oku lepszym przy zachowaniu korekcji okularowej,

c) ograniczenia pola widzenia do 20 stopni $^{1}$.

Podstawę powyższego rozróżnienia stanowią kryteria medyczne - ostrość widzenia (visus) oraz zakres pola widzenia. Stopień obniżenia ostrości wzroku w stosunku do normy wyrażany jest w postaci ułamka zwykłego lub dziesiętnego. Osoby z ostrością wzroku 0,00 uważane są za całkowicie niewidome. Sytuacja ta określana bywa jako tzw. czarna ślepota. Obecnie jednak termin ten nie jest uznawany za fortunny, gdyż nabrał znaczenia pejoratywnego. Znacznie liczniejszą grupę stanową niewidomi z resztkami wzroku (szczątkowo widzący). Ich ostrość widzenia mieści się w obszarze 0,01-0,05, co oznacza, że jest ona co najmniej dwudziestokrotnie obniżona i zachowane zostało jedynie 1-5\% zwykłej ostrości wzroku. Z kolei mianem słabowidzących określa się osoby, których ostrość widzenia mieści się wg różnych szacunków w obszarze pomiędzy 0,05 a $0,25 / 0,30$, czyli jest obniżona co najmniej trzykrotnie w stosunku do normy ${ }^{2}$.

Kolejne kryterium - zawężenie pola widzenia - wyrażane jest w stopniach. Prawidłowo funkcjonujący układ wzrokowy umożliwia spostrzeganie obiektów każdym okiem na obszarze o kącie $150^{\circ}$ $\mathrm{w}$ płaszczyźnie poziomej i $120^{\circ} \mathrm{w}$ pionowej. Widzenie obuoczne zapewnia pole widzenia o zakresie $200^{\circ}$. Ograniczenie pola widzenia kwalifikujące do słabowzroczności rozpatrywane jest jako umiarkowane $\left(60-20^{\circ}\right)$, znaczne $\left(20-25^{\circ}\right)$, a poniżej $5^{\circ}$ uważane jest za głębokie.

${ }^{1}$ J. Kuczyńska-Kwapisz J., Dzieci niewidome i stabowidzące, Centrum Metodyczne Pomocy Psychologiczno-Pedagogicznej MEN, Warszawa 2004, s. 9.

2 T. Majewski, Dzieci z uszkodzonym wzrokiem i ich edukacja, [w:] Poradnik dydaktyczny dla nauczycieli realizujacych podstawe programowa w zakresie szkoty podstawowej i gimnazjum z uczniami niewidomymi i słabo widzacymi, red. S. Jakubowski, Ministerstwo Edukacji Narodowej, Warszawa 2001, s. 17; Z. Sękowska, Rehabilitacja dzieci niewidomych i stabowidzących, [w:] Z. Sękowska, Wprowadzenie do pedagogiki specjalnej, Akademia Pedagogiki Specjalnej, Warszawa 2001, s. 98. 
Stąd też z medycznego punktu widzenia w grupie osób z uszkodzeniem wzroku wyróżnia się: całkowicie niewidome, niewidome z resztkami wzroku (szczątkowo widzące) oraz słabowidzące ${ }^{3}$.

Ponadto ze względów funkcjonalnych istotny jest aspekt temporalny. W tym kontekście dokonuje się podziałów na osoby: z uszkodzeniem wzroku od urodzenia lub wczesnego dzieciństwa oraz całkowicie lub częściowo ociemniałe, które przestały widzieć w późniejszym etapie życia, wskutek działania choroby postępującej lub nieszczęśliwego wypadku4

Podział na osoby niewidome i ociemniałe warunkowany jest zatem wiekiem, w jakim wzrok został utracony. Kryterium to wygenerowane jest możliwością zdobycia i utrwalenia w pamięci wrażeń wzrokowych przydatnych $\mathrm{w}$ dalszym życiu. Zatem przy wadach wrodzonych oraz utracie wzroku przed 4-5. rokiem życia uznaje się człowieka za niewidomego. $Z$ kolei osoby ociemniałe to te, które przestały widzieć w późniejszym czasie, a wyćwiczone do tego czasu umiejętności widzenia umożliwiły im dobrą orientację $w$ terenie i prawidłowy rozwój fizyczny5. Ociemniali znajdują się jednak, szczególnie w początkowym etapie - o czym będzie jeszcze mowa $\mathrm{w}$ niniejszym opracowaniu - w o wiele trudniejszej sytuacji psychologicznej niż niewidomi, których psychikę chroni tzw. przystosowanie pierwotne. Często aż do wieku młodzieńczego dzieci niewidome traktują brak wzroku jako coś naturalnego. Nie znają innego świata. W odróżnieniu od nich, osoby ociemniałe przeżywają poczucie rozpaczy i dojmującej straty, prowadzącej często do załamania psychicznego ${ }^{6}$.

Na potrzeby rehabilitacji zawodowej, zatrudnienia oraz ustalania rent, ulg i innych przywilejów wprowadzono w Polsce klasyfikację określającą stopień niepełnosprawności wzrokowej na pod-

${ }^{3}$ Z. Sękowska, op. cit., s. 98.

4 T. Majewski, op. cit., s. 17.

5 Z. Sękowska, op. cit.

${ }^{6}$ L. Kowalewski, Psychologiczna $i$ społeczna sytuacja dzieci niepetnosprawnych, [w:] Dziecko niepetnosprawne w rodzinie, red. I. Obuchowska, WSiP, Warszawa 2005, s. 65-68. 
stawie wyników badań okulistycznych. Głównym kryterium jest tu ustalony poziom ubytku ostrości widzenia (V). Za prawidłowy uznaje się visus równy $1(\mathrm{~V}=1)$, a niepełnosprawność wzrokową określa się jako:
a) stopień znaczny przy $\mathrm{V}=0-0,05$,
b) stopień umiarkowany przy $\mathrm{V}=0,05-0,10$,
c) stopień lekki - V=0,11-0,30.

Znaczny stopień niepełnosprawności przyznawany jest również osobom z lunetowym widzeniem, u których pole widzenia zawężone jest koncentrycznie do $20^{\circ}$, niezależnie od poziomu ostrości widzenia. Zgodnie $\mathrm{z}$ tą samą zasadą stopień umiarkowany orzeka się u ludzi z polem widzenia ograniczonym do $30^{\circ}$, a w grupę osób ze stopniem lekkim włączane są osoby jednooczne ${ }^{7}$.

Wykres 1. Podział stopni niepełnosprawności

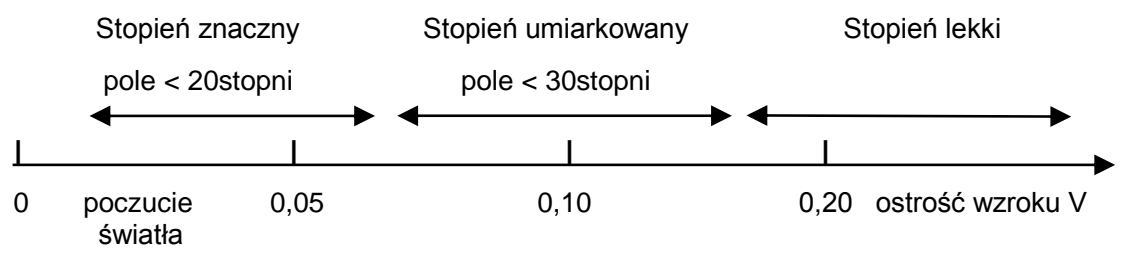

za: D. Piekut-Brodzka, J. Kuczyńska-Kwapisz, Pedagogika specjalna dla pracowników socjalnych, Warszawa 2009, s. 89.

\section{Przyczyny utraty wzroku}

Uszkodzenie narządu wzroku może nastąpić wskutek zadziałania rozmaitych czynników natury endogennej lub egzogennej, co skutkuje częściowym bądź całkowitym zaburzeniem czynności wzrokowych. Wśród najczęściej występujących grup przyczyn po-

${ }^{7}$ M. Kalbarczyk, Świat otwarty dla niewidomych. Szanse i możliwości, WSiP, Warszawa 2004, s. 15. 
wodujących schorzenia lub uszkodzenia wzroku u dzieci wymienia się: genetyczne, wrodzone wady, uszkodzenia perinatalne, wcześniactwo, choroby zakaźne przebiegające z wysoką gorączką, nowotwory, cukrzycę, awitaminozę oraz urazy mechaniczne, termiczne i chemiczne. Często nie udaje się rozpoznać pierwotnej przyczyny uszkodzenia wzroku, toteż $\mathrm{w}$ wielu przypadkach etiologia ma charakter idiopatyczny ${ }^{8}$.

Problemy przekazu wadliwych genów dotyczą przede wszystkim dzieci z dziedziczną zaćmą (kataraktą), dziedzicznym zanikiem nerwu wzrokowego, zespołem Stargardta, wysoką krótkowzrocznością, zwyrodnieniem plamki żółtej, barwnikowym zwyrodnienie siatkówki, aniridią, albinizmem ocznym czy achromatopsją. Niektóre $\mathrm{z}$ tych wad mają charakter postępujący.

Wady wrodzone spowodowane są głównie chorobami matki w okresie prenatalnym. Do szczególnie niebezpiecznych dla rozwoju narządu wzroku czynników teratogennych należą: różyczka, odra, kiła, toksoplazmoza oraz zatrucia ciążowe i alkohol. W dalszym ciągu spustoszenie sieje retinopatia wcześniacza (ROP) - schorzenie występujące wyłącznie $u$ dzieci przedwcześnie urodzonych. Wcześniactwo jest czynnikiem poważnego ryzyka niedorozwoju narządu wzroku bądź jego uszkodzenia wskutek długotrwałego działania wolnych rodników w inkubatorze 9 .

Do postnatalnych przyczyn powstawania słabowzroczności lub ślepoty należą choroby postępujące (jaskra, zaćma, nowotwory oka i inne) oraz niektóre choroby ogólnoustrojowe (cukrzyca, gruźlica, albinizm zapalenie opon mózgowych, zapalenie mózgu, guzy mózgu itp.). Duże znaczenie ma nieprawidłowa dieta, pozbawiona witaminy A. Odnotowuje się wiele przypadków pourazowego uszkodzenia wzroku, następującego podczas niewłaściwej zabawy bądź wypadku10.

8 Z. Sękowska, op. cit.

${ }_{9}^{9}$ M. Walkiewicz-Krutak, Zaburzenia w rozwoju zdolności widzenia, praca niepublikowana, 2007.

10 T. Majewski, op. cit.; M. Walkiewicz-Krutak, op. cit. 
Zofia Sękowska podkreślała, że:

Przyczyny utraty wzroku nie są obojętne dla rozwoju psychofizycznego dziecka. Występuje tu kilka zagadnień szczegółowych, które muszą być brane pod uwagę przy interpretacji tego rozwoju i przy koncepcji kształcenia niewidomego. Sprawą pierwszoplanową jest wyjaśnienie, czy przyczyna, która spowodowała utratę wzroku, nie uszkodziła jednocześnie kory mózgowej ${ }^{11}$.

U wielu chorych niepełnosprawność wzrokowa sprzężona jest z inną wadą rozwojową, np.: uszkodzeniem słuchu, niepełnosprawnością intelektualną, wadą serca czy epilepsją ${ }^{12}$.

\section{Funkcjonalne następstwa utraty wzroku}

Niewidomi (oraz ociemniali) i słabowidzący stanowią grupę niezwykle zróżnicowaną pod względem funkcjonowania wzrokowego. Schorzenia czy uszkodzenia narządu wzroku wywołują zmiany w układzie wzrokowym skutkujące znacznym obniżeniem ostrości widzenia oraz ubytkami w polu widzenia (centralnymi, obwodowymi, połowicznymi lub rozsianymi), rozmyciem oglądanego obrazu czy światłowstrętem. Te problemy z kolei generują powstanie wtórnych funkcjonalnych następstw zaburzeń widzenia w postaci: pogorszenia postrzegania kolorów, zmniejszenia wrażliwości na kontrast, zaburzenia poczucia głębi, zwiększonej wrażliwości na olśnienia, problemów z adaptacją do światła i ciemności, męczliwości i łzawienia ${ }^{13}$.

Z powyższych powodów jakość widzenia osób słabowidzących oraz niewidomych $\mathrm{z}$ resztkami wzroku (ociemniałych) warunkowana jest odpowiednio stosowanym: oświetleniem, kontrastem,

11 Z. Sękowska, op. cit., s. 105.

12 T. Majewski, op. cit.

${ }^{13} \mathrm{G}$. Walczak, Stymulacja umiejętności widzenia stabo widzących dzieci, Warszawa 1998; M.A. Duffy, Ocena i modyfikacje otoczenia dla osób stabowidzacych, "Zeszyty Tyflologiczne" 2002, nr 20. 
kolorem i fakturą. Operowanie tymi czynnikami podczas adaptacji przestrzeni oraz przygotowywania pomocy ma istotne znaczenie nie dla poczucia bezpieczeństwa i orientacji w przestrzeni.

Niektóre spośród licznych konsekwencji utraty wzroku są szczególnie dotkliwie odczuwane przez tę grupę osób niepełnosprawnych. Dotkliwa i trwała frustracja, powodowana ograniczonymi możliwościami lub całkowitym brakiem możliwości osiągnięcia danej rzeczy lub stanu, potęguje trudności z zaakceptowaniem swojej sytuacji. W literaturze przedmiotu podnoszone są kwestie ograniczeń poznawczych i estetycznych, obejmujących m.in.: wizualne poznawanie świata, nieadekwatność wyobrażeń w myśleniu czy schematyzm pojęć jak również zmniejszenie wrażeń estetycznych z dziedziny malarstwa, architektury, twórczości artystycznej. Utrata widzenia w znacznym stopniu wpływa na możliwość kształcenia się, znajomość literatury naukowej, poezji, prasy. W bardzo istotny sposób ogranicza wypowiadanie się na piśmie i korespondencję. Zmniejsza $\mathrm{w}$ znacznym stopniu dostępność rynku pracy, a tym samym wybór zawodu i drogi życiowejej ${ }^{14}$.

Utrata widzenia ogranicza możliwości realizacji potrzeb osobistych, takich jak: swoboda ruchów, możliwość uniknięcia bólu, przykrości czy leczenia, budowanie poczucia własnej wartości i siły oraz aktywizacja swoich pragnień i predyspozycji. Niewidomy doświadcza wielu trudności $\mathrm{w}$ samodzielnym poruszaniu się, a tym samym załatwianiu swoich spraw urzędowych i osobistych. W nieznanym otoczeniu nieustająco narażony jest na urazy mechaniczne, uderzenie się, upadek. Staje się potencjalną ofiarą wypadków komunikacyjnych, sam również może być jego sprawcą. Ta świadomość hamuje swobodę ruchów i chęć eksplorowania świata. Ograniczenia przestrzenne $\mathrm{w}$ dużej mierze pozbawiają niewidomego człowieka niezależności i skazują na opiekę innych ludzi. Nawet jeśli przewodnik jest życzliwy i oddany, nieustanna konieczność liczenia się z wolą innego człowieka, komunikowania się z nim

${ }^{14}$ D. Piekut-Brodzka, J. Kuczyńska-Kwapisz, Pedagogika specjalna dla pracowników socjalnych, Akademia Pedagogiki Specjalnej, Warszawa 2009, s. 90. 
i pozostawania w zależności fizycznej ujemnie odbija się na psychice osoby ociemniałej.

Powyższe problemy ograniczają uczestnictwo niepełnosprawnych w życiu społecznym. Doświadczają oni często współczucia, czując się przez to „innymi”, niepełnowartościowymi ludźmi. Potrzeba szacunku i zachowania poczucia osobistej godności musi wielokrotnie ustępować poczuciu własnej bezradności i bezsilności wobec drwin i upokorzeń. Istotnie zmniejszone zostają szanse zaspokojenia potrzeby miłości i pozostawiania w bliskiej relacji, a także bycia samodzielnym i niezależnym od innych.

Warto podkreślić, że choć każdemu ociemniałemu życie nie szczędzi trosk i rozczarowań, to za trudniejszą ocenia się sytuację kobiet niż mężczyzn. Wpływa na to wiele czynników. Zdaniem M. Orłoś:

Niewidoma kobieta ma większe trudności w dbaniu o swój wygląd zewnętrzny. Jej ubiór jest bardziej zróżnicowany w kształtach i kolorach, częściej bywa zmieniany i uzupełniany różnymi dodatkami (broszki, korale, kolczyki itp.). Utrzymanie fryzury i pielęgnacja twarzy też może sprawiać jej dużo trudności. W rodzinie przypada kobiecie prowadzenie gospodarstwa domowego, utrzymanie czystości, przyrządzenie posiłków, pranie oraz pielęgnacja niemowląt i wychowywanie dzieci. Te różnorodne i skomplikowane czynności wymagają wszechstronniejszego i większego usprawnienia niż u mężczyzn ${ }^{15}$.

\section{Z kolei Marek Kalbarczyk twierdzi, że:}

Jak każda kobieta, tak i kobieta ociemniała pragnie serdeczności i ciepła rodzinnego. Pragnie wyjść za mąż i mieć dzieci. Jakże jednak trudno zrealizować te pragnienia. dla niewidomego mężczyzny założenie rodziny na ogół nie stanowi problemu. Najczęściej żenią się z kobietami widzącymi, uzyskując z ich strony miłość i troskliwą opiekę. Do nader rzadkich wypadków należy wyjście za mąż niewidomej kobiety za widzącego mężczyznę. Nawet niewidomy mężczyzna woli żonę

${ }^{15}$ M. Orłoś, Doświadczanie niepetnosprawności w autonarracji osoby tracacej wzrok, niepublikowana praca magisterska 2013, s. 15-16. 
widzącą niż niewidomą. Jeśli mimo tego spotykamy znaczny odsetek niewidomych mężatek, to rekrutują się one z kobiet ociemniałych już po wyjściu za mąż $\dot{z}^{16}$.

\section{Przeciwko ograniczeniom}

Przy zachowaniu określonych warunków znaczenie i dotkliwość wielu spośród wyżej wymienionych ograniczeń może zostać zmniejszona. Nadawaniu nowej jakości życiu osoby ociemniałej sprzyja rozwój cywilizacyjny, przede wszystkim dostęp do nowoczesnych osiągnięć technologicznych, które ułatwiają komunikowanie się i orientację w rzeczywistości. Nowoczesne media wpływają na zwiększanie się społecznej wiedzy o niepełnosprawności i kształtują pozytywne postawy. Coraz powszechniejszy staje się dostęp do audiodeskrypcji $\mathrm{w}$ miejscach publicznych i instytucjach kultury (fundacjakatarynka.pl). Dzięki temu niewidomi również stają się coraz bardziej otwarci na kontakty z innymi, chętniej biorą udział $\mathrm{w}$ życiu towarzyskim i kulturalnym ${ }^{17}$. Coraz więcej urzędów ma wykwalifikowany i życzliwy personel, który pomaga osobom niepełnosprawnym $\mathrm{w}$ załatwieniu ich spraw. Na uczelniach działają rzecznicy do spraw studentów niepełnosprawnych. Wiele organizacji pozarządowych podejmuje inicjatywy umożliwiające niewidomym i ociemniałym budowanie wiary w siebie i pozytywnej samooceny.

By jednak móc dostrzec własną siłę i poczuć się pełnowartościowym człowiekiem, osoba ociemniała musi przejść długą i trudną walkę ze sobą samą i światem, określaną w psychologii jako proces przystosowania się do niepełnosprawności. Przebieg tego procesu, warunkowany wieloma czynnikami, ma bezpośredni wpływ na jakość dalszej egzystencji18.

${ }^{16}$ M. Kalbarczyk, op. cit., s. 72.

17 A. Ostrowska, Kiedyś niewidoczni, jak jest dziś?, http://www.instytutobywa telski.pl [16.09.2015].

18 L. Kowalewski, op. cit. 


\section{Metoda - studium indywidualnego przypadku}

Jakościowe studium przypadku jest dość powszechnie stosowaną metodą przeprowadzania badań w naukach humanistycznych i społecznych ${ }^{19} \mathrm{i}$

stanowi złożoną całość, usytuowaną $\mathrm{w}$ określonym otoczeniu, środowisku oraz zakorzenioną w wielu kontekstach. Przedmiotem zainteresowania badacza, oprócz samego przypadku, staje się jego tło historyczne, zaplecze kulturowe i fizyczne oraz konteksty: społeczny, ekonomiczny, polityczny, etyczny i estetyczny ${ }^{20}$.

O wyborze studium przypadku jako metody badawczej często decydują nie tyle względy proceduralne, ile zainteresowania badacza konkretnym problemem i chęć poszukiwania jego cech typowych oraz wyjątkowych. W pedagogice specjalnej i dziedzinach pokrewnych często dzieje się tak, że case studies stanowią źródła hipotez i pomysłów na temat normalnego zachowania i jego zaburzeń 21 .

Metoda studium przypadku często jest wykorzystywana do badania rzadkich zjawisk. Wartość naukowa tej metody w pedagogice specjalnej uważana jest za wysoką, bowiem realizuje zarówno cele naukowe, jak i praktyczne, gdyż: „czasami opisuje zastosowanie i wyniki konkretnego oddziaływania lub leczenia, na przykład nowej techniki terapeutycznej w wypadku osób z zaburzeniami emocjonalnymi"22. Z powyższych względów wybór tej właśnie metody uznałam za najbardziej właściwy do przeprowadzenia analizy uzyskanych wyników w niniejszym badaniu.

19 J.J. Shaughnessy, E.B. Zechmeister, J.S. Zechmeister, Metody badawcze w psychologii, Gdańskie Wydawnictwo Psychologiczne, Gdańsk 2002; R. Stake, Jakościowe studium przypadku, [w:] Y.S. Lincoln, Metody badań jakościowych, t. 1, red. N.K. Denzin, PWN, Warszawa 2009, s. 623.

${ }^{20}$ R. Stake, op. cit., s. 632.

${ }^{21}$ J.J. Shaughnessy, E.B. Zechmeister, J.S. Zechmeister, op. cit.

22 Ibidem, s. 351. 


\section{Proces przystosowania się do niepełnosprawności}

Proces adaptacji do bycia osobą niepełnosprawną, obejmujący wszystkie sfery funkcjonowania człowieka - fizyczną, psychiczną i społeczną, został nazwany przez Lecha Kowalewskiego jako proces przystosowania do niepełnosprawności. Zgodnie z typologią, stworzoną przez tego autora, obejmuje on cztery stadia: doznania niepełnosprawności, uświadomienia sobie ograniczeń, prób funkcjonowania z niepełnosprawnością, przystosowania. Przebieg każdej z tych faz jest zróżnicowany i odmienny u poszczególnych osób, natomiast kolejność ich występowania pozostaje stała ${ }^{23}$.

\section{Doznanie niepełnosprawności}

Utrata widzenia należy do tego rodzaju dysfunkcji rozwoju, w których moment oraz stopień powstałego uszkodzenia wywierają istotny wpływ na przebieg procesu adaptacyjnego.

W fazie pierwszej - stadium doznania niepełnosprawności psychologiczna i społeczna sytuacja osoby niewidomej od urodzenia jest zupełnie inna niż takiej, która wzrok straciła w wyniku rozwijającej się stopniowo choroby lub też nagle w okresie dzieciństwa, adolescencji lub dorosłości.

Psychikę dziecka, które przyszło na świat jako niewidome, chroni mechanizm przystosowania pierwotnego. Nie dziwi się ono swojej sytuacji, nie zna innej. Jeśli doświadcza akceptacji i miłości ze strony bliskich, ma wiele okazji do zbudowania pozytywnego obra$\mathrm{zu}$ siebie ${ }^{24}$. W przeciwieństwie to takiego stanu rzeczy osoby ociemniałe doświadczają wielu gwałtownych i silnych przeżyć emocjonalnych o pejoratywnym zabarwieniu. Sytuacja taka ma miejsce zarówno wtedy, kiedy utrata wzroku następuje wskutek

\footnotetext{
${ }^{23}$ L. Kowalewski, op. cit.

24 Ibidem.
} 
postępującego schorzenia, jak i niespodziewanie - np. jako efekt wypadku komunikacyjnego czy zaniedbań lekarskich podczas leczenia innej choroby. W takich przypadkach najwyraźniejszymi przeżyciami stają się lęk i niepokój, wywołane percepcją własnej sytuacji oraz deprywacją sensoryczną. Przerażenie, panika oraz dezorientacja w świecie dominują nad wszystkimi innymi przeżyciami ${ }^{25}$.

Pani Lena nie urodziła się niewidoma. Była najmłodszą z czwórki rodzeństwa, zawsze aktywną, roześmianą, pełną energii dziewczyną. Po pomyślnie zdanych egzaminach maturalnych wyjechała do Niemiec, by tam rozpocząć życie zawodowe. Wkrótce jednak okazało się, że jest poważnie chora. Po powrocie do Polski rozpoznano $\mathrm{u}$ niej białaczkę o ostrym przebiegu. Lena została poddana chemioterapii, a następnie przeszczepowi szpiku kostnego. Ze względu na poważną operację oraz prawie całkowitą utratę odporności organizmu, rekonwalescencja i powrót do zdrowia trwały długo. Jednakże, kiedy trzy lata później zdecydowała się spełnić swe dawne marzenie i rozpoczęła kurs nauki jazdy samochodem, wszystko wydawało się być już w jak najlepszym porządku. Pewnego dnia w czasie prowadzenia auta dziewczyna zauważyła pogarszający się stan pogody. Była zaskoczona szybkim rozprzestrzenianiem się mgły, o czym powiedziała instruktorowi. Ten zdumiony odpowiedział, że jest słoneczne, bezchmurne popołudnie. Zaniepokojona Lena poprosiła go, by odwiózł ją do domu. Dzień później była już w klinice okulistycznej. Niestety nie udzielono jej tam właściwej pomocy. Każdego dnia wiele godzin spędzała pod drzwiami kolejnych gabinetów, gdzie jej problemy utożsamiano jedynie ze stanem zapalnym oczu. Tymczasem Lena bezradnie doświadczała jak świat staje się dla niej coraz ciemniejszy i mniej wyraźny. Dopiero po wielu interwencjach udało jej się dotrzeć do specjalisty, który poważnie potraktował stan jej zdrowia. Oczy poddano kilku operacjom. Lena na pewien czas odzyskała wzrok. Okazało się jednak, że to tylko cisza przed burzą i na ocalenie widzenia było już za późno. Nikt wów-

${ }^{25}$ Ibidem. 
czas nie wiedział, że wiele miesięcy wcześniej wskutek braku odporności po walce organizmu z nowotworem, została zainfekowana toksoplazmozą. Brak właściwego rozpoznania etiologii trudności $\mathrm{z}$ widzeniem uniemożliwił prawidłowe sformułowanie diagnozy i leczenia. Lena bezpowrotnie straciła wzrok i w wieku 21 lat stała się osobą ociemniałą26.

Sama wspomina ten czas w następujący sposób:

Przełomem była kolejna operacja, po której obudziłam się, nic nie widząc. Pierwszy raz znalazłam się $\mathrm{w}$ takiej sytuacji, że nie widziałam nawet osób, które obok mnie leżały. Lekarz utrzymywał mnie w nadziei, że widzenie w ciągu dwóch, tygodni powinno powrócić. Gdy po kilku tygodniach okazało się, że wróciło jedynie widzenie cząstkowe i nie jestem wielu rzeczy zrobić samodzielnie, załamałam się. Przestawałam już rozpoznawać ludzi na ulicy ponieważ nie miałam ostrości widzenia, wszystko było delikatnie rozmazane. Pamiętam to napięcie, kiedy szłam przez miasto i stres, że mogę mijać znajome mi osoby, a ja ich nie rozpoznaję. Często ktoś do mnie mówił cześć, a ja przez długi czas zastanawiałam się kto to mógł byćp ${ }^{27}$.

Utrata wzroku, w połączeniu z samotnością i poczuciem deprywacji sensorycznej wywołują uczucia o tak silnym zabarwieniu pejoratywnym, że u wielu osób mogą prowadzić nie tylko do załamania, ale i do depresji. Osoba, której wzrok uległ zniszczeniu w sposób gwałtowny i niespodziewany - a tak właśnie było w przypadku Leny - nie jest w stanie szybko poradzić sobie z poczuciem deprywacji sensorycznej. Jej układ nerwowy nie wykształcił jeszcze kompensacyjnych umiejętności zmysłowych. Przed niebezpieczeństwem nie chroni ani słuch, ani dotyk. Świat jawi się jako obcy, nieznany i niebezpieczny. Człowiek staje się nieporadny, bezbronny jak niemowlę, a zależność od innych bywa krępująca i trudna do zniesienia $^{28}$.

\footnotetext{
${ }^{26}$ M. Orłoś, op. cit.

${ }^{27}$ M. Orłoś, op. cit., s. 55.

${ }^{28}$ L. Kowalewski, op. cit.; Z. Sękowska, op. cit.
} 
Zdolność do przetrwania tego kryzysu i stosunkowo szybkie przejście do etapu drugiego - stadium uświadomienia sobie ograniczeń, bezpośrednio zależy od zasobów wewnętrznych jednostki i powinna być rozpatrywana $\mathrm{w}$ ramach koncepcji resilience ${ }^{29}$.

\section{Uświadomienie sobie ograniczeń}

Najznamienniejszą cechą tego etapu jest przeżywanie długotrwałego poczucia dysonansu poznawczego. Psychiczny świat człowieka ociemniałego skoncentrowany jest wówczas na rozpatrywaniu poczucia rozpaczy spowodowanej utratą wzroku. Wszystko, co było kiedyś wydaje się atrakcyjniejsze i lepsze do tego, co teraz. Świat miniony wydaje się barwny i przepełniony szczęściem, a przyszłość nieodmiennie kojarzy się z lękiem i samotnością ${ }^{30}$. Osoba ociemniała musi skonfrontować się ze swoimi ograniczeniami i próbować dostrzec swoje nowe możliwości - choć to ostanie przez długi czas wydaje się nieosiągalne.

Codzienne sytuacje nastręczają wielu trudności. Zanim osoba niewidząca nauczy się, jak bardzo idealny porządek i ład pomagają jej opanować otaczającą ją rzeczywistość, zapewne podobnie jak Lena - godzinami siedzi w bezruchu na łóżku, bojąc się wstać i nie stłuc niczego, nie zrobić sobie krzywdy. Dziewczyna długo nie wiedziała, gdzie znajdują się jej rzeczy, nie umiała rozpoznać ich kształtu. Wszystko wokół wydawało się zbyt ostre, zbyt nieprzewidywalne, zbyt niebezpieczne. Okazało się wtedy, że szczegóły - tak łatwo pomijane przez widzących - mają ogromne znaczenie. Musiała zapamiętać, jak i w którą stronę otwierają się wszystkie okna,

${ }^{29}$ E.E. Werner, Risk, resilience, and recovery: Perspectives from Kauai Longitudinal Study, "Development and Psychopathology" 1993, nr 5, s. 503-515; E.E. Werner, Protective factors and individual resilience, www.healthychild.ucla.edu [16.09.2015]; E.E. Werner, R. S. Smith, Journeys from Childhood to Midlife: Risk, Resilience, and Recovery, Cornell University Press, Ithaca and London 2001; R. Walthes, Tyflopedagogika, Gdańsk 2007.

${ }^{30}$ L. Kowalewski, op. cit. 
drzwi i szafki w domu oraz znaleźć precyzyjne miejsce dla każdej rzeczy. Pomogło to nie tylko orientować się $\mathrm{w}$ przestrzeni, ale i uniknąć potencjalnych niebezpieczeństw czy urazów. Nauczyła się korzystać z mebli i innych sprzętów jako punktów orientacyjnych na mapie mieszkania oraz zachowywać niewielkie, puste ciągi komunikacyjne, umożliwiające swobodne poruszanie się¹.

O ile opanowanie przestrzeni własnego domu wydaje się stosunkowo łatwe po pewnym czasie, o tyle świat na zewnątrz pozostaje chaotyczny i przerażający na długo. Wśród sytuacji, które szczególnie utkwiły wówczas Lenie $\mathrm{w}$ pamięci, były m.in. takie, w których ktoś obcy niespodziewanie i bez słowa ciągnął ją za rękę, próbując zapewne pomóc przejść przez ulicę. Wywoływało w niej to jedynie poczucie paniki i chaosu. Pewnego dnia, podejmując próbę bycia samodzielną, wsiadła do autobusu, który pojechał w zupełnie innym kierunku niż się spodziewała. Nie wiedząc zupełnie gdzie jest, poczekała aż wszyscy wysiądą i dopiero wtedy zdecydowała się przedstawić swoją sytuację kierowcy. Ten odprowadził ją do właściwego autobusu ${ }^{32}$.

Lena, tak wówczas, jak i jeszcze długo potem, nie chciała być i nie była postrzegana jako osoba niewidoma. Wstydziła się używać białej laski. Jest piękną dziewczyną, a utrata widzenia dopiero w dorosłości sprawiła, że nie ma najmniejszych trudności z wykonaniem starannego makijażu czy dobraniem sobie efektownej fryzury. Bardzo ładnie się ubiera, estetycznie komponując całość stroju. Zalety te okazały się być jednak mieczem obosiecznym. Z jednej strony Lena, pragnąc zachować niezależność, doświadczała podziwu ze strony znajomych. $\mathrm{Z}$ drugiej, nie korzystając z białej laski, narażała się na niezrozumienie w sytuacjach społecznych. W czasie studiów wykładowcy zwracali jej uwagą na nieadekwatne w ich ocenie zachowanie Leny, która np. nie notowała z tablicy lub też patrzyła w innym kierunku niż proszono. Zdarzało się, że ludzie na

\footnotetext{
${ }^{31}$ M Orłoś, op. cit.

32 Ibidem.
} 
przystankach nie odpowiadali, kiedy pytała o numer nadjeżdżającego tramwaju czy autobusu ${ }^{33}$.

Sytuacje te skłoniły ją do pierwszych prób chodzenia z białą laską. Nieporadne wtedy poczynania opisała w słowach:

Drogę znałam wcześniej i mogłam tam iść już bez laski, ale głupio mi było ją nagle schować do torebki i pójść sobie, jakbym nagle odzyskała wzrok. Stwierdziłam, że czas się przełamać i zaczęłam z nią iść. Nie było to łatwe, bo nie wiedziałam nawet jak ją prawidłowo trzymać. Chodniki były krzywe ciągle mi się gdzieś zahaczała, jednocześnie wbijając mi się w brzuch. Miałam ochotę ją wyrzucić. Gdy przechodziłam przez przejście, nagle ktoś bez żadnego słowa złapał mnie pod rękę. Nie wiedziałam nawet, czy to kobieta czy mężczyzna. Po jakimś czasie odezwał się i zapytał, czy idę w stronę dworca. Odpowiedziałam, że tak. On zaczął prowadzić mnie w lewo, powiedziałam, że nie, dziękuję, bo ja idę w prawo i sama sobie już poradzę. Wtedy mnie puścił. Kiedy doszłam do autobusu i usiadłam w nim, szybko złożyłam laskę i schowałam ją do torebki. Powiedziałam sobie, że więcej jej nie użyję bo mam więcej stresu niż bez niej. Dopiero wtedy napięcie zaczęło mi stopniowo opadaćs4.

Gwałtownym przemianom ulega nie tylko obraz świata zewnętrznego. Zmianie ulegają nie tylko częstotliwość, ale i rodzaj interakcji. Człowiek ociemniały spotyka się głównie z członkami najbliższej rodziny oraz z przyjaciółmi. Ze względu na zobowiązania zawodowe i inne, a także odległość od miejsc zamieszkania kontakty te bywają nieczęste. Naturalną konsekwencją takiego stanu rzeczy jest fakt, iż osoba która od niedawna nie widzi, doświadcza samotności i pustki. Jest zbyt przerażona, by samodzielnie wyjść z domu i zbyt słabo jeszcze orientująca się w nowy sposób w świecie, by móc zrobić to bezpiecznie. Staje się całkowicie zależna od pomocy i dobrej woli innych ludzi. Przyjaźnie, miłości i więzi rodzinne zostają wystawione na trudną próbę. Ci spośród ociemniałych, którzy do tej pory byli aktywni i niezależni, podwójnie gorzko

33 Ibidem.

34 Ibidem, s. 56. 
przeżywają tę zmianę 35 . Lena szczególnie dotkliwie wspomina ten aspekt bycia niepełnosprawną. Dotąd zawsze roześmiana i pełna życia, została zamknięta w czterech kątach, nieustająco czekając na to, aż ktoś bliski znajdzie dla niej czas. Dziś, śmiejąc się, opowiada, że nie wie skąd akurat w tamtym momencie znalazła siły, by przeprowadzić się z ówczesnym chłopakiem do Wrocławia, podjąć studia i walczyć o swoją niezależność. Ten etap swojego godzenia się z utratą wzroku Lena wspomina bowiem najboleśniej. Choć każdy, kto poznał tę wesołą dziewczynę, miałby trudność, by w to uwierzyć, to tamten czas w jej życiu był przepełniony bólem, łzami i rozpaczą. Nie należała do nikogo. Nie czuła się już zdrowa, nie czuła się ociemniała. Przede wszystkim zaś nie czuła się sobą ${ }^{36}$.

\section{Próby funkcjonowania z niepełnosprawnością}

Lena długo jeszcze miotała się w poczuciu bezradności. Cały czas coś robiła - studiowała, przeprowadzała się, spotykała się z ludźmi... Nie wiedziała jednak w jakim kierunku i celu zmierza jej życie. W międzyczasie przeżywała rozmaite przygody - niektóre zabawne, inne smutne. Doświadczała i życzliwości, obojętności, a nawet wrogości ze strony znajomych. Jej kilkuletni związek nie przetrwał tej próby. Z czasem zaczęła robić się coraz odważniejsza i bardziej niezależna w swoich wyprawach i poczynaniach. Mimo to ciągle żyła na huśtawce stresu periodycznego, rozdarta między wiarą w siebie a poczuciem rozpaczy ${ }^{37}$.

Przełomem, który pozwolił jej nabrać wiatru w żagle, był dzień, w którym odważyła się sama poszukać pomocy. Zdecydowała się na kontakt z organizacją pozarządową, która zaoferowała jej możliwość wyjazdu na obóz survivalowy dla osób z różnymi rodzajami

${ }^{35}$ L. Kowalewski, op. cit.

${ }^{36}$ M. Orłoś, op. cit.

37 B. Cytowska, Trudne drogi adaptacji, Oficyna Wydawnicza „Impuls”, Warszawa 2012; L. Kowalewski, Psychologiczna i społeczna sytuacja dzieci niepetnosprawnych, [w:] Dziecko niepetnosprawne..., op. cit. 
niepełnosprawności. Doświadczenie to udowodniło Lenie, jak wiele potrafi pomimo ograniczeń, jakie niesie ze sobą brak wzroku. I - co może ważniejsze - inni ludzie dostrzegają i doceniają jak ma trudno, a mimo to walczy. Wśród uczestników tamtej wyprawy w Bieszczady byli ludzie po amputacjach, niesłyszący oraz Lena, jedyna niewidoma. Wspomina to doświadczenie w słowach:

Praktycznie wszystko robiliśmy tam sami, przyrządzaliśmy jedzenie na butlach gazowych lub na ognisku, na które wcześniej w lesie zbieraliśmy drewno, sami rozbijaliśmy i składaliśmy namioty, ciągle się przemieszczaliśmy $\mathrm{w}$ nowe miejsca, co było dla mnie dużym utrudnieniem. Jak już poznałam nowy teren, to znów trzeba było się przemieszczać i czułam się wtedy zagubiona i dużo bardziej zmęczona psychicznie. Robiliśmy między innymi tam ćwiczenia, w których uświadamialiśmy sobie nawzajem swoje niepełnosprawności. Na zmianę poruszaliśmy się z zawiązanymi oczami, gdzie jedna osoba ukierunkowywała inną bądź oprowadzała. Płynęliśmy w parach kajakiem na wyspę, tam oprowadzaliśmy siebie na przemian po terenie z przepasanymi oczami. Ja, prowadząc kolegę, kierowałam się osobami z przodu, które dostrzegałam, gdy oni skręcili w prawo ja także skręciłam wpatrując się $\mathrm{w}$ nich aby ich nie zgubić, nie widziałam nic poza nimi (...). W tym skupieniu zapomniałam, że prowadzę kolegę, który centralnie twarzą uderzył w drzewo. Po tym doświadczeniu szedł już bardzo niepewnie i nieufnie. Ja go tylko pocieszałam tym, że do takich niespodzianek można się przyzwyczaić, ja mam tak na co dzień. Wracając, to ja sterowałam kajakiem, a kolega $\mathrm{z}$ zawiązanymi oczami zdziwił się kiedy dopłynęliśmy do brzegu, bo przez całą drogę miał wrażenie, że stoimy w miejscu. Po tym stresującym dniu usłyszałam od nich że nie chcieliby być na moim miejscu wola już być bez nogi niż nie widzieć. Po tych ćwiczeniach mogłam poczuć się, że mnie lepiej rozumieją ${ }^{38}$.

Tamten obóz ukierunkował jej dalsze cele i działania. Razem członkami fundacji „Poza Horyzonty” zaczęła uczestniczyć w projekcie „Razem na szczyty”, a potem jeździć także na wyprawy rowerowe. Poznała ludzi, których polubiła. Ich adekwatne reakcje na

${ }^{38}$ M. Orłoś, op. cit., s. 61. 
jej stan, pozwoliły Lenie rozpocząć wewnętrzy proces ponownego integrowania osobowości, rozbitej traumatycznym doświadczeniem ociemnienia. Wytworzyła w sobie zgodę na życie w nowy sposób i do pewnego stopnia zaczęła identyfikować się z osobami niepełnosprawnymi.

Praktyczne i przynoszące sukcesy próby pokonywania niepełnosprawności pomogły jej nauczyć się doceniać każdy drobny sukces. Wytworzona w ten sposób motywacja osiągnięć pomogła trwale zmodyfikować perspektywę widzenia własnej niepełnosprawności, która z koncentracji na ograniczeniach i poczuciu straty przekształciła się w dążenie do doskonalenia sprawności i ponownego opanowania utraconych umiejętności ${ }^{39}$. Pomocne okazały się również życzliwe reakcje innych, nienoszące znamion pseudoakceptacji. Ci, którzy naprawdę pomogli, nie okazywali nadmiernego współczucia, nie wyręczali, nie prowadzili za rękę więcej niż było to konieczne. Dzięki temu Lena, mogła powiedzieć:

Poznałam tam wspaniałych ludzi. Dzięki wspólnym wyprawom nabrałam wiatru w żagle, odżyłam na nowo. Znów mogłam powrócić do aktywności. Wyjazdy i przebywanie wśród ludzi pomogły mi w powrocie do normalności. (...) Kontakty, jakie nawiązałam na wyprawach, zmniejszyły też moje poczucie osamotnienia. Łatwiej mi funkcjonować z poczuciem, że niedaleko są ludzie, na których mogę polegać w trudnych momentach. Czuję się poprzez to spokojniejsza. Ta zmiana sytuacji spowodowała, że z osoby wycofanej, niepewnej i pogrążonej w strachu stałam się osobą otwartą, zadowoloną z życia, cieszącą się tym co $\operatorname{mam}^{40}$.

Mechanizmy identyfikacji i kompensacji, akceptacja ze strony innych, w tym całej rodziny sprawiły, że Lena ukierunkowała swoje dążenia i mogła zacząć formułować w sposób celowy swoją przyszłość. Ukończyła studia uprawniające ją do pracy z osobami niepełnosprawnymi, dla których staje się pierwszym i bardzo wiarygodnym przewodnikiem w świecie po doznaniu niepełnosprawności.

\footnotetext{
${ }^{39}$ L. Kowalewski, op. cit.

${ }^{40}$ M. Orłoś, op. cit., s. 62.
} 


\section{Przystosowanie do niepełnosprawności}

Niewidomy Marek Kalbarczyk uważa, iż:

Pierwszoplanową rolę w ukształtowaniu wysokiego poczucia własnej wartości pełni akceptacja swojej niepełnosprawności. Uświadomienie sobie ograniczeń wynikających z tego faktu - bez nadmiernego smutku czy rozpaczy - jest tak samo ważne jak skoncentrowanie się na mocnych stronach osobowości, na możliwościach osiągnięcia sukcesu (choć oczywiście w ograniczonym zakresie i nie we wszystkich dziedzinach) bez iluzorycznych złudzeń co do zdecydowanej czy cudownej poprawy swojego wzroku. Akceptacja straty i uznanie braku jako czegoś nieodwracalnego jest poważnym problemem dla wielu osób tracących wzrok. Właściwy stosunek do siebie i do własnej niepełnosprawności umożliwia realną ocenę swoich możliwości, a także pozwala odzyskać szacunek dla samego siebie, jeśli został on utracony ${ }^{41}$.

Życie Leny po utracie wzroku jest dowodem prawdziwości tych słów. Procesy rozpoczęte w poprzednim etapie znajdują swoje ukoronowanie $\mathrm{W}$ ostatniej fazie procesu adaptacyjnego. "Centralne miejsce, wśród przekonań na temat własnej osoby, przestają zajmować informacje o niepełnosprawności (...) Obraz własnej niepełnosprawności staje się jednym z wielu elementów obrazy własnej osoby" 42 . Dziś Lena ponownie jest aktywną, młodą i atrakcyjną kobietą, która czerpie z życia pełnymi garściami. Świadoma swych możliwości, ale i ograniczeń, rozsądnie podejmuje działania i wybiera zadania. Chętnie bierze udział w życiu kulturalnym. Pozostaje krytyczna wobec środowiska tyflopedagogicznego, które uznaje za skostniałe i nieprzydatne. Ceni współpracę z nowoczesnymi organizacjami pozarządowymi. To w nich upatruje sojuszników w rozbudowywaniu sieci udogodnień ułatwiających niewidomym i ociemniałym poruszanie się po mieście czy szukanie pracy. Podjęła działalność zawodową, lecz nie ukrywa, że nie jest ona szczytem

\footnotetext{
${ }^{41}$ M. Kalbarczyk, op. cit., s. 6.

${ }^{42}$ L. Kowalewski, op. cit., s. 91.
} 
jej marzeń. Pod pozorem braku odpowiedniego pomieszczenia w biurze, zorganizowano jej pracę przy komputerze w domu.

Doświadczenia, które ukształtowały osobowość Leny na nowo, nie były łatwe. Zakończyły się powodzeniem z dwóch głównych powodów. Naczelnym z nich są osobowość i siły wewnętrzne mojej bohaterki, które uchroniły ją przed załamaniem i wypaleniem się sił. Równie ważne okazały się być jednak kontakty z innymi ludźmi. Dzięki nim Lena może dziś powiedzieć:

Czasami czuję, że z nadmiaru pozytywnej energii mogłabym zawojować świat. Chłonę każdą chwilę, mam też siłę do przełamywania barier. To nie znaczy jednak, że nie miewam gorszych chwil. Bywa tak, że gromadzą mi się sytuacje, w których odczuwam bariery związane z utratą wzroku i czuję się poprzez to wykluczona z pewnych działań. Czasami też mam już dość ciągłego chodzenia z kimś pod rękę, potykanie się, mojej nieporadności. Bywa, że tęsknię za poczuciem wolności, swobody i niezależności. Na początku mojego niewidzenia czułam dużą blokadę w sobie, będąc w nowym miejscu, byłam zablokowana i zazwyczaj siedziałam w jednym miejscu, bo wstydziłam się wstać i gdzieś dojść, wiedziałam, że wzrok ludzi będzie na mnie skupiony. Wstydziłam się swojej ślepoty, niezaradności, tego że ktoś musi mnie nakierowywać $w$ lewo, w prawo, tam sa drzwi, przesun się. (...) W takich chwilach czułam się mało atrakcyjnie. $Z$ czasem to wszystko się zmieniało, poprzez wiele pozytywnych informacji, które otrzymuję od ludzi. Pomagają one mi wiele rzeczy sobie uświadomić, poukładać i zrozumieć. Dziś czuję, że odzyskałam równowagę emocjonalną i poczucie własnej wartości. Na nowo czuję się 100\% kobietą i wcale nie czuję się gorsza od innych ${ }^{43}$.

Najcharakterystyczniejszym elementem umożliwiającym rozpoznanie, że niepełnosprawność stała się już tylko jednym z wielu, a nie dominującym aspektem życia człowieka, jest jego zdolność do śmiania się z własnej sytuacji. Poczucie humoru i śmiech mają właściwości odstresowujące. $Z$ radością czytałam anegdoty o zabawnych epizodach z życia Leny, która np. w myślach umawiała się

${ }^{43}$ M. Orłoś, op. cit., s. 62. 
z archaniołem Gabrielem, by ten pomógł jej odnaleźć zamek w furtce, kiedy bała się, wracając do domu sama w środku nocy lub też dziwiła się zaskoczeniu wykładowców akademickich, którzy nie orientowali się, iż ta śliczna dziewczyna nie widzi ${ }^{44}$.

\section{Blaski i cienie bycia niewidomym w XXI w. Wnioski}

Utrata wzroku była dla mojej bohaterki czymś niespodziewanym. Nigdy wcześniej nawet nie pomyślała, że może ją coś takiego spotkać. Dochodząc do zdrowia po białaczce, nie przypuszczała, że kolejny raz jej życie wywróci się do góry nogami i legnie w gruzach. Był to czas, kiedy żyła w ciągłym lęku o to, że szpik kostny mógł zostać odrzucony przez organizm. Ponadto w sposób traumatyczny doświadczała pogarszania się wzroku. Kiedy ostatecznie go utraciła, załamała się. Znalazła się w punkcie zerowym, w którym była uzależniona od pomocy innych. Wszystkiego musiała się uczyć od nowa. Czuła się bezbronna, odczuwała poczucie silnego zagrożenia, utraciła wiarę w siebie i w to, że w ogóle będzie w stanie kiedykolwiek żyć samodzielnie. Emocje, jakie jej towarzyszyły w ten czas, to przede wszystkim poczucie totalnej pustki i osamotnienia. Wszystko, co się działo wokół, dla niej nie istniało, toczyło się poza jej światem. Była zawieszona w próżni, której nikt poza nią nie był w stanie zrozumieć, bo ona sama nie rozumiała, co się z nią dzieje. Lena czuła się ciężarem dla innych, zwłaszcza dla swego ówczesnego partnera, który wielokrotnie wytykał jej nieporadność. Oczekiwał od niej, że od razu będzie w stanie radzić sobie samodzielnie. Powodowało to w niej silną frustrację i negatywne emocje, które się w niej gromadziły i nie mogły znaleźć ujścia, gdyż ona sama czuła się uwięziona w swoim ciele. Pogrążona w żalu i rozpaczy nie wiedziała jak sobie z tym wszystkim poradzić. Mieszkając w obcym mieście, nie miała żadnego wsparcia z zewnątrz. Jedynym oparciem

${ }^{44}$ M. Orłoś, op. cit. 
dla niej była wiara w Boga, która dawała jej nadzieję na lepsze jutro45.

Punkt zwrotny w życiu Leny nastąpił po rozstaniu z partnerem. Zaczątkiem budowania nowej tożsamości było uczestnictwo $\mathrm{w}$ projekcie, w którym brała aktywny udział. Zaczęła przebywać wśród nowo poznanych osób. Po raz pierwszy spotkała się z tym, że jej niepełnosprawność nie rzuca się w oczy. Ci ludzie dodawali jej otuchy pozytywnymi komunikatami. Doceniali jej wysiłki i starania, byli pełni podziwu, że tak dobrze sobie radzi. Coraz pewniej stawiała kroki ku nieznanej przyszłości. Idąc ciągle do przodu, rozwija się i odzyskuje radość z uroków życia. Pozwala jej to na realizację celów i pokonywanie barier wzrokowych. Ponadto Lena przez cały czas odczuwała akceptacje swojej osoby i wszystkich działań ze strony swojej rodziny ${ }^{46}$.

Dziś Lena twierdzi, że nadal jest $\mathrm{w}$ trakcie adaptowania się do swojej niepełnosprawności, ale powoli następuje w niej akceptacja i pogodzenie się z tym stanem. Pomaga jej w tym świadomość tego, że i tak dużo otrzymała od losu, pokonując chorobę nowotworową. Te wszystkie zdarzenia spowodowały, że czuje się silniejsza i odporniejsza na trudne sytuacje. Pozwala jej to na budowanie nowego życia jako osoby z niepełnosprawnością wzrokową. By dojść do tego momentu, musiała przejść wiele trudnych etapów, które były konieczne, by mogła stać się tą osobą, którą dziś jest. Brak wzroku nie spowodował u niej wyłącznie strat, ale pozwolił jej stworzyć nowe spojrzenie na życie. Poznaje świat i ludzi od zupełnie innej strony. Wcześniej nie dostrzegała wielu rzeczy, które teraz nabrały innego znaczenia. Utrata wzroku spowodowała przewartościowanie życia ${ }^{47}$.

Lena pomaga profesjonalnie osobom, które znalazły się w takiej sytuacji jak ona kiedyś. Stoję na stanowisku, iż jest w tym niezastąpiona. Dzięki swoim doświadczeniom jest nie tylko wiarygodna i autentyczna. Przede wszystkim ma:

\footnotetext{
${ }^{45}$ L. Kowalewski, op. cit.; M. Orłoś, op. cit.

${ }^{46}$ M. Orłoś, op. cit.

47 Ibidem.
} 
teraz świadomość, że nikt nie jest w stanie zrozumieć sytuacji drugiej osoby, emocji w ten czas odczuwanych, dopóki sam czegoś takiego nie przeżyje. Może się wydawać, że rozumie się drugą osobę, ale gdy znajdzie się w podobnej sytuacji okazuje się, że wcześniejsze rozumienie było powierzchowne i niejednokrotnie błędne ${ }^{48}$.*

* Podczas przygotowywania artykułu miałam możliwość korzystania z niepublikowanej pracy magisterskiej Doświadczanie niepełnosprawności w autonarracji osoby tracacej wzrok, za co serdecznie dziękuję jej Autorce.

\section{Bibliografia}

Cytowska B., Trudne drogi adaptacji, Oficyna Wydawnicza „Impuls”, Warszawa 2012.

Duffy M.A., Ocena i modyfikacje otoczenia dla osób stabowidzących, „Zeszyty Tyflologiczne", nr 20, Warszawa 2002.

Kowalewski L., Psychologiczna $i$ spoteczna sytuacja dzieci niepetnosprawnych, [w:], Dziecko niepetnosprawne $w$ rodzinie, red. I. Obuchowska, WSiP, Warszawa 2005.

Kuczyńska-Kwapisz J., Dzieci niewidome i stabowidzące, Warszawa 2004.

Kalbarczyk M., Świat otwarty dla niewidomych. Szanse i możliwości, Warszawa 2004.

Majewski T., Dzieci z uszkodzonym wzrokiem i ich edukacja, [w:] Poradnik dydaktyczny dla nauczycieli realizujacych podstawe programowa w zakresie szkoty podstawowej i gimnazjum z uczniami niewidomymi i stabo widzacymi, red. S. Jakubowski Ministerstwo Edukacji Narodowej, Warszawa 2001.

Orłoś M., Doświadczanie niepetnosprawności w autonarracji osoby tracacej wzrok, niepublikowana praca magisterska. 2013.

Ostrowska A., Kiedyś niewidoczni, jak jest dziś?, http://www.instytutobywatelski.pl [31.10.2015], za: Piekut-Brodzka D., Kuczyńska-Kwapisz, Pedagogika specjalna dla pracowników socjalnych, Wydawnictwa Akademii Pedagogiki Specjalnej im. Marii Grzegorzewskiej, Warszawa 2009.

Sękowska Z., Rehabilitacja dzieci niewidomych i stabowidzacych, [w:] Sękowska Z., Wprowadzenie do pedagogiki specjalnej, WSPS, Warszawa 2001.

Shaughnessy J.J., Zechmeister E.B., Zechmeister J.S., Metody badawcze w psychologii, GWP, Gdańsk 2002.

Stake R., Jakościowe studium przypadku, [w:], Metody badań jakościowych, red. N.K. Denzin, Y.S. Lincoln, t. 1, PWN, Warszawa 2009.

${ }^{48}$ M. Orłoś, op. cit., s. 64-65. 
Walczak G., Stymulacja umiejętności widzenia słabo widzacych dzieci, WSiP, Warszawa 1998.

Walkiewicz-Krutak M., Zaburzenia w rozwoju zdolności widzenia, praca niepublikowana, 2007.

Walthes R., Tyflopedagogika, GWP, Gdańsk, 2007.

Werner E.E., Risk, resilience, and recovery: Perspectives from Kauai Longitudinal Study, "Development and Psychopathology", 5, 1993, s. 503-515.

Werner E.E., Protective factors and individual resilience, www.healthychild.ucla.edu [31.10.2015].

Werner E.E., Smith R.S., Journeys from Childhood to Midlife: Risk, Resilience, and Recovery, Cornell University Press, Ithaca and London 2001. 